\title{
Interplay between Technology and Meaning: How Music Majors Reacted?
}

\author{
Daniel TRABUCCHI \\ (corresponding author) \\ School of Management - Politecnico di Milano \\ daniel.trabucchi@polimi.it \\ Elena PELLIZZONI \\ School of Management - Politecnico di Milano \\ elena.pellizzoni@polimi.it \\ Tommaso BUGANZA \\ School of Management - Politecnico di Milano \\ tommaso.buganza@polimi.it \\ Roberto VERGANTI \\ School of Management - Politecnico di Milano \\ roberto.verganti@polimi.it
}

This is a post-print version of the paper published on the Creativity Innovation Management:

Trabucchi, D., Pellizzoni, E., Buganza, T., \& Verganti, R. (2017). Interplay between technology and meaning: How music majors reacted?. Creativity and Innovation Management, 26(4), 327-338.

https://onlinelibrary.wiley.com/doi/full/10.1111/caim.12234 


\begin{abstract}
The diffusion of digital technologies enables companies to propose new business, products and services. Business environment is characterized by increasing level of competition and customers can choose a growing number of solutions. In this scenario, companies seek for new dimension of innovation: the meaning. A strong debate took place among scholars on the strategies that company may use to react to the external innovations. So far, the phenomenon was analyzed grounded in the technology-push literature. The goal of this research is to understand if these strategies are still valuable even if the innovators leverages not only on the technology but also on a hedonic dimension proposing an innovation of meaning. Through a multiple case studies analysis - based on both primary and secondary sources - we investigate if the companies used the strategies described in the literature to cope with technological innovations also for innovations that leverage both on technology and meaning. Leveraging on the literature, a triple-dimension analysis is performed considering boundary management strategies, incumbent configuration and complementary capabilities. The music industry has been used as empirical field and the behaviors of three Music Majors have been studied. Indeed, they faced significant innovations based on the interplay between technology and meaning being able to survive and maintain their role in the industry.

Our results show that incumbents leveraged on both boundary management (e.g. merger and acquisition) and incumbent configuration (Manage the organization and employees' roles) strategies as suggested by literature. Moreover, they focus only on the dynamic component of complementary capabilities in order to create and capture value leveraging the new meaning.

The companies react to external innovation both re-interpreting the current solution through new meaning and proposing new solutions. Theoretical and managerial implications are drawn as well as avenues for future research.
\end{abstract}




\section{Introduction}

Due to the pervasive spread of digital technologies, in the last few decades the competitive scenario changed significantly (e.g. Brynjolfsson and McAfee, 2014). The diffusion of digital technologies contributed in enabling companies to create out-of-scratch new businesses, new products and new services able to challenge the dominant paradigms (e.g., Downes and Nuens, 2013).

These changes in the business environment created a more complex competitive arena, where companies need to face a larger number of competitors (e.g., Brynjolfsson et al., 2013) and customers have to choose among a wide array of opportunities, that is often too rich and confusing and jeopardize their ability to understand what solution is the best for them (e.g., Schwartz, 2004). Companies face greater difficulties in emerging within the competitive arena, since the diffusion of digital technologies created a common technological base that all companies - both start-up and established - can leverage on (Buganza et al., 2015). Therefore, companies need to find different dimensions of innovation and ways to emerge in this complex scenario (e.g., Verganti, 2017).

Consider for example, the hotel industry, where the digital revolution unveiled two different ways to approach the market. Companies, like Booking.com, created an online environment to book rooms (technological substitution). While, other new entrants tried to leverage on the value embedded in the digital technology providing a new meaning to their services. Lodging in a private house through AirBnb means having the chance to meet new people and live in someone else shoes for a few days and not only renting a physical space to sleep. These kind of innovations are changing the dimensions along which the competition takes place: from the functional level to the hedonic one (e.g., Beltagui et al., 2012; Candi et al., 2015).

These innovations have been widely investigated in recent literature (e.g. Verganti, 2009; Norman and Verganti, 2014; Simoni et al, 2014; Dell'Era et al, 2017). Verganti (2009) proposed the theory of Design-Driven Innovation, considering Design the right approach to move the innovation process towards the hedonic dimension of products. It is a pushing innovation that changes completely the reason-why customers use a product, a breakthrough with a high chance of diffusion in the future society (Verganti, 2011).

This theory originates from the comprehension of subtle dynamics in socio-cultural models, resulting in the proposal of radically new meanings and languages. The meaning defines why a product is used, not how it works. The radical innovation of meaning is a change in the interpretative paradigm of what make sense, both from the innovating company's point of view 
(they see a change of their strategic vision) and from the customer's point of view (that sees a change in the purposes). In other words, a new meaning is not achieved just thinking creatively: it shall also come from an interaction with the society and mainly with external players (Verganti and Oberg, 2013).

The overlap between Technology-Push and Design Driven Innovations draws others reflections (Dell'Era et al., 2010; Norman and Verganti, 2014; Dell'Era et al., 2017). By finding a new meaning within an existing technology, companies can pursue a technology epiphany, changing the dominant paradigm (Verganti, 2009; Buganza et al., 2015).

As occurs in tech-based innovations, established companies are not always able to survive at meaning-driven innovation. In the GPS-turn-by-turn navigation system industry, for example, Waze changed the meaning of the products. Leveraging on users as data-source and real time information on traffic conditions it unveils a new meaning: customers can use their smartphones to reach everyday destinations through the smartest and fastest path and avoiding traffic jams. The new meaning destroyed the incumbents' position and companies like Garmin and TomTom were not able to face the disrupting force of the new entrant (Buganza et al., 2015). This dynamic doesn't always apply though, and some established companies proved to be able to master the innovative meaning proposed by new entrants (e.g. Navionics in Buganza et al., 2015).

Existing companies facing the challenge of technology-push discontinuities have been the focus of a relevant stream of literature. Researchers started from the incumbent's curse and deeply studied strategies, dimensions and advantages that established companies can rely on to successfully remain on the market (e.g. Christensen, 1997, 2006; Adner, 2002; Rothaermel, 2001; Hill and Rothaermel, 2003; Rothaermel and Hill, 2005). The aim of this research is to understand if and how those strategies, dimensions and advantages highlighted in the existing literature are still valuable when the innovation is different in nature; when it is not based on just technology but on the interplay between technology and meaning.

The paper is structure as follows: in the next Section the authors propose an overview of the academic contributions on the Incumbent's curse and the implementable strategies to overcome it. Section 3 focuses on the research design, presenting the empirical setting, the methodology applied in the inquiry and the data gathering and analysis process. Section 4 and 5 describe the results and discuss them through the theoretical lenses presented in the theoretical background. Finally, contributions and the limitations of this study are presented in the last section which also highlights a few avenues for further researches in this field. 


\section{Theoretical Background}

The theoretical background of this research is grounded on studies regarding the strategies, implemented by incumbents in order to react after a technology discontinuity proposed by new entrants.

The impact of technology innovations on the competitive scenario is largely explored in literature. It is well known that innovations that deeply transform industries, reshape competitive advantages and hinder organizational and economic sustainability of exiting firms (Schumpeter, 1942; Abernathy and Clark, 1985; Tushman and Anderson, 1986).

A large debate involved scholars in order to discover how incumbent firms are affected by technology innovations proposed by new entrants (e.g. Christensen, 1997, 2006; Adner, 2002; Rothaermel, 2001; Hill and Rothaermel, 2003; Rothaermel and Hill, 2005). Established companies suffer facing this kind of innovations. Technological changes can shake the market and incumbents can be replaced by new entrants with strategic incentives to work on that radical innovation (Foster, 1986; Henderson, 1993; Bower and Christensen 1995; Christensen and Bower, 1996; Christensen, 1997). This stream of literature focuses on understanding why incumbents fail after technology discontinuities. The term incumbent's curse describes precisely how the incumbent on a specific market is stuck with its success or hampered by its bureaucracy and fails to connect with the next generation of radically new products (Chandy and Tellis, 2000). Incumbents tend to develop incremental innovations that evolve from their previous products and their efforts towards the new technologies are often marked by incompetence and underinvestment (Henderson, 1993; Chandy and Tellis, 2000). Even if incumbents should manage the trade-offs between the different generations of products, they often lean towards the past (Gawer and Cusumano, 2008). They are concentrated on current value networks and technological paradigms (Macher and Richman, 2004). New entrants instead are flexible and focused on dislodging the dominant standards (Tushman and Anderson, 1986; Christensen and Rosenbloom, 1995).

However, incumbents can actually be able to win the challenge and face technological discontinuities (Methe et al, 1997; King and Tucci, 2000, 2002; Leifer at al, 2000; Cohan, 2000; Ahuja and Lampert, 2001; Hill and Rothaermel, 2003; Rothaermel and Hill, 2005). Many real examples in different industries support this empirical evidence (e.g. typesetting: Tripsas, 1997; medical devices: Methè et al 1997, financial industry: Cohan, 2000; personal computer: Gawer and Cusumano, 2008). The debate among scholars suggests that established companies may have learned how to cope with external technological innovations. They are now more keen to 
enter new market niches although they still need more time (King and Tucci, 2000). Incumbents strategies lead them to long term survival (Chesbrough, 2003).

Scholars investigated deeply and extensively this phenomenon and incumbent-challenger dynamics are summarized by Ansari and Krop (2012). Three levels of analysis are presented: industry setting, incumbent firm and challenge. Due to the aim of this research, the following overviews focuses on the firm level analysis. Ansari and Krop (2012) describe the (dis)advantage of incumbent splitting them in three areas: boundary management, incumbent configuration and complementary capabilities. Leveraging on their framework, the following sections summarize the main strategies, based on incumbents' advantages, that established companies can rely on to react to technological discontinuities.

\section{Boundary management}

Ansari and Krop (2012) argue that "the more incumbents engage in symbiotic cross-boundary management (i.e. effective partnerships with challenger firms), the higher the chances of incumbent survival when faced with radical innovations". In this vein, companies can adopt three different strategies (see Table 1).

First of all, companies can leverage on inter-organizational collaboration, in order to repair their locus of innovation when, through external innovators, knowledge base in the industry is expanding (e.g. Powell et al., 1996). Several relationships with other companies can be built and exploited, such as cooperative networks or licensing (Chesbrough, 2006; Macher and Richman, 2004; Rothaermel, 2001; Sampson, 2005; Kapoor and Adner, 2011; Hillman et al., 2009). Established companies can leverage on Service Value Networks that represent the relationships among players involved in the process to provide the product or service to the ultimate users of a given innovation (e.g., Rosenbloom and Christensen, 1994; Tripsas, 1997). Networks of strategic alliances can also help incumbents in exploring the boundaries and boosting their position on the market (Lambe and Spekman, 1997; Rosenkopf and Nerkar, 2001; Rothaermel and Boeker, 2008). Moreover, incumbents can focus their efforts on the upstream innovation in order to maintain the advantage on new entrants (Adner and Kapoor, 2010). Leverage on supplier relationships can be a strategy to keep focusing on the core business - e.g. system architecture - and outsource the other components increases the chance to be impacted by new entrants' innovations (Brusoni et al., 2001).

In case of industries with weak intellectual property regimes corporate ventures may increase incumbents' innovation rate (Dushnitsky and Lenox, 2005). Merger and acquisition, indeed, can lead incumbents to strengthen their competitive position. As suggested by the Resource 
Dependence Theory, vertical integration can reduce the environmental interdependence and uncertainty (Adner and Kapoor, 2010; Hillman et al. 2009). Moreover, leveraging financial capabilities, established firms can acquire the innovators or set up joint-ventures with them (Helfat and Leiberman, 2002; Iansiti et al., 2003; Macher and Richman, 2004).

$\begin{array}{ll}\text { Bnter-organizational collaboration } & \begin{array}{c}\text { Boundary } \\ \text { management } \\ \end{array} \\ & \text { Powell, et.al, 1996; Lambe and Spekman, 1997 } \\ & \text { Rothaermel, 2001; Rosenkopf and Nerkar, 2001; } \\ & \text { Richman, 2004; Macher and Sampson, 2005; } \\ & \text { Chesbrough, 2006; Rothaermel and Boeker; 2008; } \\ & \text { Hillman et al., 2009; Kapoor and Adner, 2011 } \\ \text { Merger and Acquisition } & \text { Helfat and Leiberman, 2002; Iansiti et al., 2003; } \\ & \text { Macher and Richman, 2004; Dushnitsky and } \\ & \text { Lenox, 2005; Hillman et al., 2009; Makri et al., } \\ & \text { 2010 } \\ \text { Leverage on supplier relations } & \text { Rosenbloom and Christensen, 1994; Tripsas, 1997; } \\ & \text { Adner and Kapoor, 2010; Brusoni et al., 2001; } \\ & \text { Rothaermel, 2001; Macher and Richman, 2004; } \\ & \text { Sampson, 2005; Chesbrough, 2006; Kapoor and } \\ & \text { Adner, 2011 }\end{array}$

Table 1 - Boundary management strategies

\section{Incumbent configuration}

Incumbents can adapt their formal organization, both from a macro and from a micro perspective, in order to become more capable to foster innovation and to react to external innovations (Ansari and Krop, 2012), summarized in Table 2.

Managing properly the organization and employees' roles can play a key role in that process. Incumbents should carefully choose the organizational structures, level of autonomy of divisions, degree of centralization and formalizations (Aiken and Hage, 1971; Cardinal 2001; Westerman et al., 2006). Organic and informal structures, with high degree of autonomy and decentralization, and mechanisms for inter-functional collaboration can lead incumbents to a successful survival (Hill and Rothaermel, 2003; MacMillan and Selden, 2008; Pierce and Delbecq, 1977; Hage, 1999; Damanpour, 1991). Moreover, when a radical innovation occurs, companies shall hire new employees that add a positive value: they could either be experts of the new technology or simply people with a vision coherent with the new environment. Maier (1982) recommended the reallocation of human resources and the increase in workers' mobility, both within companies and from one organization to another. Moreover, to successfully face a technological change coming from new entrants, the role of employees' involvement in term of emotional identity plays a key role (Podolny et al., 2004; Voss et al., 2006). 
Incumbents should also still work on current businesses and technologies. Exploring continuously a broad set of options and realigning current activities, can lead incumbents to a competitive advantage (Thomond et al., 2003; Cattani, 2005). To cope with a radical technological innovation, companies indeed should look for the long-term efficiency of the mature units to compete both in the old and new market (e.g. O'Reilly and Tushman, 2008).

\section{Incumbent configuration}

$\begin{array}{ll}\text { Manage the organization and employees' roles } & \text { Aiken and Hage, 1971; Pierce and Delbecq, 1977; } \\ & \text { Maier, 1982; Damanpour, 1991; Hage, 1999; } \\ & \text { Cardinal, 2001; Hill and Rothaermel, 2003; Podolny } \\ & \text { et al., 2004; Voss et al., 2006; Westerman et al., 2006; } \\ & \text { MacMillan and Selden, 2008 } \\ \text { Work on current businesses and technologies } & \text { Cohen and Levinthal, 1990; Klepper and Simons, } \\ & \text { 2000; Thomond et al., 2003; Cattani, 2005; O'Reilly } \\ & \text { and Tushman, 2008 }\end{array}$

Table 2 - Incumbent strategies

\section{Complementary capabilities}

The third dimension is related to complementary capabilities (Ansari and Krop, 2012) and it is summarized in Table 3. It can be considered as a wider view on the definition of complementary assets proposed by Teece (1986). Complementary assets are the resources required to capture the benefits associated with a strategy, a technology, an innovation; moreover, they are also a critic factor to select who will benefit from an innovation. Among them, we can find specialized technologies, that facilitates the product development and the efficiency of the supply chain in the face of an innovation (e.g. Tripsas, 1997). Those specific assets are even more valuable after a technological discontinuity that destroys an upstream competency of the incumbent: in such a case, the specialized technologies may help the incumbent to overcome the problem and manage a good commercial performance (Teece, 1986; Barney 1991; Tripsas, 1997). Another relevant asset is the privileged access to distribution channels, that effectively prevents the threat of new entrants, indeed incumbents benefit from their priority in the most attractive locations and distribution spaces (e.g. Mittal and Swami, 2004; Cohen and Levinthal, 1990; Klepper and Simons, 2000). Moreover, complementary technologies can play a key role: if incumbents own them, they can reduce the span of opportunities for new entrants (Teece, 1986). Incumbents shall be always ready to acquire the complementary technologies through mergers and acquisitions (Makri et al., 2010).

Furthermore, facing a technological innovation also means to evaluate the chance to modify the business model (Teece, 2010; Zott et al., 2011). Technology-push innovations can change the market, the value chain, the revenue mechanism, the cost structure and the position in the value 
network of a company. Incumbents may react by switching to a new business model. Incumbents' managers must expand their perspectives to find what is valuable to the market, changing the value proposition, and/or change the mechanisms to capture that value (Chesbrough and Rosenbloom, 2002; Chesbrough, 2010; Teece, 2010; Zott et al., 2011).

Finally, incumbents have to become customer-oriented, focusing not only on current customer needs but also on future ones (Chandy and Tellis, 1998; Danneels, 2004). Incumbents can take advantages on understanding the latent and unexpressed needs of their customers (Slater and Narver, 1998).

\author{
Leverage on specialized technologies \\ Complementary capabilities \\ Teece, 1986; Barney, 1991; Tripsas, 1997 \\ Leverage on a Privileged Access to Distribution \\ Teece, 1986; Cohen and Levinthal, 1990; Klepper \\ Channels \\ and Simons, 2000; Mittal and Swami, 2004 \\ Leverage on complementary technologies \\ Teece, 1986; Makri et al., 2010
}

Change of the Value Proposition

Chesbrough, 2010; Teece, 2010; Zott et al., 2011

\section{Change of the Value Capturing}

Being customer-oriented
Chesbrough and Rosenbloom, 2002; Chesbrough, 2010; Zott et al., 2011

Dannel, 2004; Taylor and Helfat, 2009; Slater and

Narver, 1998; Chandy and Tellis, 1998

Table 3 - Complementary capabilities strategies

This theoretical background offers an overview on the advantages and the related strategies that incumbents can rely on to react to challenges proposed by external innovators in a competitive environment. The debate on how incumbent firms facing external innovation are grounded on technology-push innovations literature (e.g. Christensen, 1997, 2006; Adner, 2002; Rothaermel, 2001; Hill and Rothaermel, 2003; Rothaermel and Hill, 2005). The aim of this research is to understand if these strategies are still valuable even if the innovators leverages also on a hedonic dimension proposing an innovation of meaning.

\title{
Research Design
}

This research project is based on longitudinal exploratory case studies, develops a contextualized analysis and leverages on primary and secondary sources with a retrospective nature (Yin, 1998). We aim at identifying strategies that companies used to react after innovations based on the interplay between technology and meaning (Eisenhardt and Graebner, 
2007). Following Gibbert et al. (2008) we used existing theories to help us interpreting the data coming from our case study analyses, getting internal validity.

\section{Area of investigation and case study methodology}

In order to provide an answer to our research question, we needed an empirical field with two main characteristics: first, it had to be challenged by external innovations based on the interplay between technology and meaning and, second, its incumbents were able to survive to these innovations.

The Recorded Music industry matches these characteristics. Several new entrants approached the market leveraging on the interplay between technology and meaning. From late 90s, the industry experienced many relevant changes: from the CD to the peer-to-peer services, from MP3 to iTunes, etc. Many new entrants, as You Tube or Spotify, entered the market bringing new meanings and new technologies. Nevertheless, Music Majors (MM) still exist, even if they were six and now after some M\&A they are three, still representing, though, more than $88 \%$ of the market ${ }^{1}$.

\section{Sampling}

The sampling process was designed in order to increase robustness of the analysis and generalizability of the results leveraging literary and theoretical replication (Yin, 1998). We included in the analysis all the incumbents: the three MM. The three cases (Figure 1) have been developed following a literary replication approach, aiming at highlighting similarities and differences in the behaviors, in order to corroborate each other.

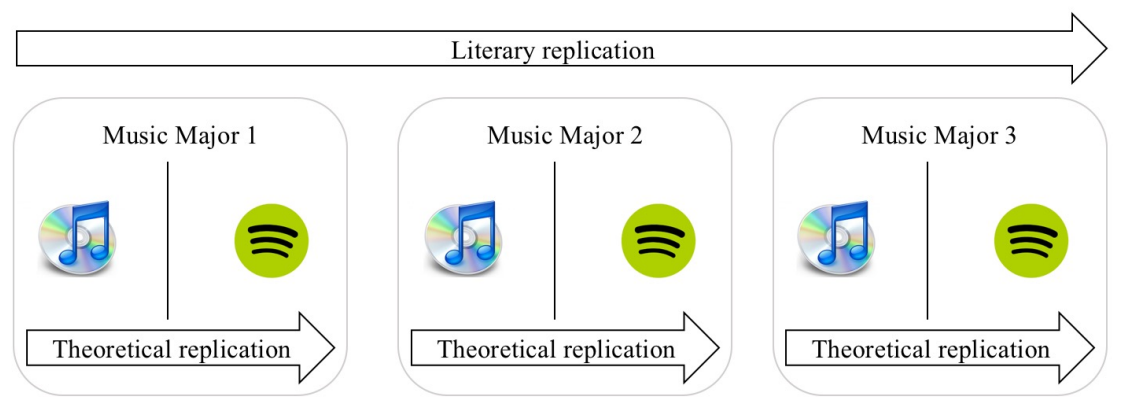

Figure 1 - Sampling

Moreover, in order to cover different theoretical conditions, we designed a theoretical replication research and analyzed the strategies applied by different companies to react to the same innovations, (Yin, 1998): iTunes by Apple and Spotify. Both innovations are

\footnotetext{
${ }^{1}$ http://www.businesswire.com/news/home/20130104005149/en/Nielsen-Company-Billboard's-2012-Music-Industry-Report
} 
characterized by the interplay between technology and meaning. In 2003 Apple presented iTunes exploiting the potentialities of the audio encoding technology and proposing a new meaning: that is your music, the music you chose according to your own tastes, being able to buy even a single song out of an album, without any kind of imposition, supporting the artist you love (Verganti, 2009, 2017). Spotify (founded in 2006), leveraged the potentialities of internet first and of the smartphone then, changing again the meaning promoting music as the soundtrack of a specific moment. Users can decide to not select a track, but to select a mood, or a moment in time . An algorithm will provide the best music for that. The biggest change is related to the movement from the concept of "owning" the music (which was typical of CDs and still present in iTunes) to the concept of "owning" the access (Verganti, 2017). The two dimensions of innovation are summarized in Table 4, highlighting both the technology and the meaning side.

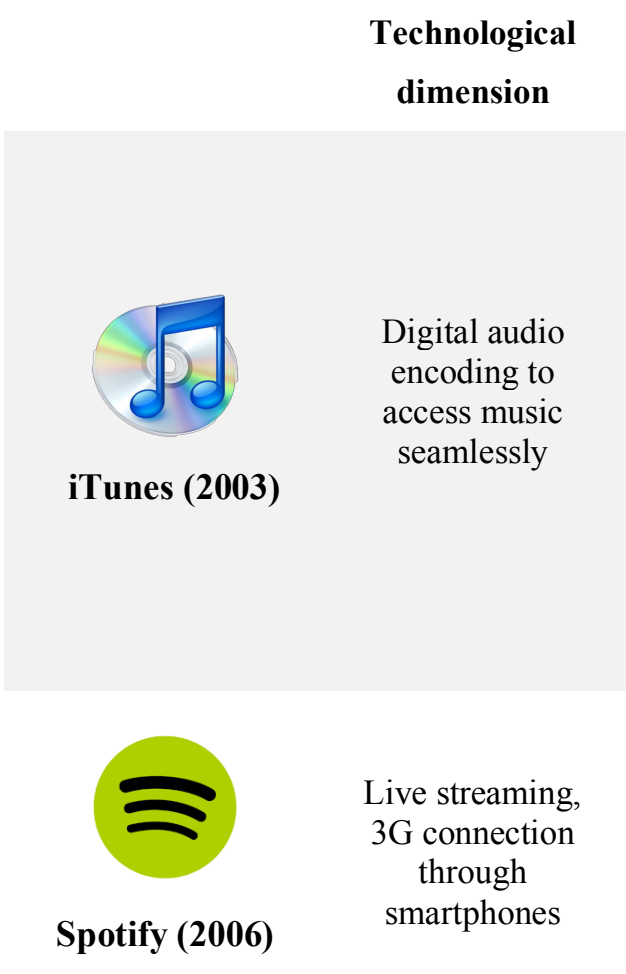

Table 4-iTunes and Spotify as innovations based on the interplay of technology and meaning

\section{Meaning \\ dimension}

"People can reproduce all their own personal music. [...] it offers a seamless experience: of discovering and tasting new music, buying music at affordable $\$ 0.99$ price (which meant that you were symbolically saying, "I'm not stealing music; I car for artists and I contribute to subsidize the industry. I'm a producer for new artists"), storing and organizing music collection into personal playlists, and listening to it through the iPod)." (Verganti 2009, p. 76)

From a mean "mean to replace the Walkman as a portable music player" to "discovering and tasting new music on the iTunes Store, buying it with a click, organizing music into personal playlists, and listening to it" (Verganti, 2017, p. 73)

"Music if for everybody"; "You'll find readymade playlists to match your mood, put together by music fans and experts."

(Spotify.com)

From "I listen to a music-streaming service because I want to have easy access to music" to "I listen to a music-streaming service I want to discover new music according to the situation I am in at this moment" (Verganti, 2017, p. 215)

These two innovations match the features requested for the aim of this research. Therefore, MMs have been challenged by new entrants like iTunes and Spotify that leveraged on the interplay between technology and meaning (Table 4). If we considered them today, both iTunes and Spotify helped MMs to overcome the threatens of internet (e.g. Napster), providing them a 
new distribution channel and new revenue streams. At the same time, we need to consider the situation they faced back in the years: MMs were incumbents that were suffering the diffusion of internet and the illegal diffusion of songs online, when a giant like Apple proposed a new platform that dramatically reduce the power of the majors (that have a privileged access to distribution channels) giving the chance to reach the entire world through a single platform. Moreover, iTunes first and Spotify then represent for independent (or eventually going-to-be independent) artists the chance to be distributed and capture the visibility got through other platforms (e.g. YouTube) without the need of a Music Labels.

\section{Data gathering and data analysis}

The research is based on primary and secondary sources that have been triangulated to increase the reliability and robustness of the findings (Miles and Huberman, 1984).

Secondary sources analysis represented the first step of the data gathering phase. The aim was to increase the knowledge on the empirical field to build the protocol for the interviews. We considered three types of secondary sources: institutional websites of the companies involved in the research and websites of industry associations (e.g. RIAA for the US market, FIMI for the Italian one) to have an overview on the field and industry magazines.

Then, primary sources have been involved to understand from the inside how companies reacted to the external innovations. We interviewed one person for each MM, selected on the following criteria: they are i) top managers, in order to have comprehensive overview of strategic decisions that ii) faced directly the two transaction phases under analysis. Afterwards, in order to verify the consistency of the previous interviews, two managers from independent labels have been interviewed as well,.

A semi-structured interview protocol was designed, coherently with the exploratory nature of this research (Bryman and Bell, 2011; Yin, 2009). It included a semi-structured questionnaire which increased the data completeness and allowed us to follow the respondents' answers giving proper relevance to what emerged during the interviews (Merton et al., 1990; Yin, 2009). During the interviews, we guided the conversation in order to understand how the company reacted to the innovators' approach, asking about the different strategies presented in the literature and more general questions related to the impact on the overall business and industry. All the interviews have been divided in two main parts: the first one regarding the strategies implemented to survive after iTunes and the second one after Spotify. 
Six interviews took place between March and October 2015, lasting between thirty minutes and one hour and a half each. They have been recorded and transcribed. Managers received in advance a short description of the research project and a brief summary of the questions.

The coding has been done independently from one of the author and then validated from the two co-authors (Saldaña, 2012). Then two external researchers validate the code book, in order to increase the reliability of the research process. The information was then organized in a matrix (Miles and Huberman, 1984), allowing to compare interview results in three different ways: i) comparison between strategies applied by the three majors after iTunes; ii) comparison between strategies applied by the three majors after Spotify; iii) comparison between strategies applied after iTunes and after Spotify.

\section{Results}

In this section, we present the results of our research process. As previously highlighted, we are going to consider the data gathered through the interviews and the secondary sources analyses regarding two different innovations based on the interplay between technology and meaning: i) iTunes and ii) Spotify.

\section{Music Majors facing iTunes}

Table 5 summarizes how the three majors reacted to iTunes.

\begin{tabular}{|c|c|c|c|}
\hline & MM1 & MM2 & ММ3 \\
\hline & \multicolumn{3}{|c|}{ Boundary management } \\
\hline Inter-organizational collaboration with new partners & $\boldsymbol{v}$ & $v$ & $v$ \\
\hline \multirow[t]{2}{*}{ Merger and acquisition } & $\boldsymbol{v}$ & $\nu$ & $v$ \\
\hline & \multicolumn{3}{|c|}{ Incumbent configuration } \\
\hline Manage the organization and employees' roles & $\boldsymbol{v}$ & $v$ & $\nu$ \\
\hline \multirow[t]{2}{*}{ Work on current businesses and technologies } & $\boldsymbol{v}$ & $v$ & $v$ \\
\hline & \multicolumn{3}{|c|}{ Complementary capabilities } \\
\hline Leverage on specialized technologies & $x$ & $x$ & $x$ \\
\hline Leverage on a privileged access to distribution channels & $x$ & $x$ & $x$ \\
\hline Leverage on complementary technologies & $x$ & $x$ & $x$ \\
\hline Change of the value proposition & $\nu$ & $\nu$ & $\boldsymbol{v}$ \\
\hline Change of the value capturing & $\boldsymbol{v}$ & $\boldsymbol{v}$ & $\boldsymbol{v}$ \\
\hline Being customer-oriented & $\nu$ & $v$ & $\boldsymbol{v}$ \\
\hline
\end{tabular}

Table 5 - How companies leveraged on selected strategies to survive after iTunes

Regarding the strategies that refers to Boundary management the Majors leveraged significantly on inter-organizational collaborations. MM1 and MM2, after the rise of iTunes, 
created joint ventures and collaborations with digital providers, to propose their own digital channels.

Some activities have been partially outsourced: "In the big majors often the scouting process is outsourced, there are the talent shows and so on". MM have the chance to leverage on supplier relationships (i.e. TV broadcaster), while their value network allowed them to start creating instores within big physical stores (i.e. live events with the artists to promote the sales of physical CDs): "[Our marketing activities] now moved on the business of in-stores, we still invest, but on something else".

Moreover, all the majors acquired competitors, but also complementary businesses (e.g. tour agencies), going in the direction of vertical integration.

Considering the Incumbent configuration, all the three majors re-organized their workforce. i) creating new digital divisions to take care of the new opportunities and challenges provided by the market and/or ii) hiring new resources closer to the digital environment where the innovations were taking place: "We changed more than 50\% of the employees since we were in need of new competences on digital and we marketing".

Incumbents went on working on their mature business. All the three companies continued selling CDs even if their relevance was decreasing. The price of physical products dropped almost 30\% in less than ten years, nevertheless the manager in MM3 sais "Physical CDs still represent a good share of the distribution modalities and revenues of the music industry for $u s "$.

Finally, considering the Complementary capabilities, two different patterns emerge. First, the Majors did not leverage their specialized technologies, their privileged access to distribution channels and their complementary technologies. All the three companies continued to leverage on their complementary assets for their ordinary businesses, but they did not represent a useful lever to react to the innovator. Indeed, iTunes did not challenge MMs on their traditional market, but moved the competition outside of the traditional channels, leveraging on different complementary assets. In other words, Majors have, might have a privileged access to distribution channels, due to their long history in the business, but this is useless because iTunes proposes a new distribution channel.

In spite of that, they leveraged different strategies, focusing on their value proposition, their way to capture value and their orientation towards customers.

The three companies changed their names becoming Entertainment companies, enlarging their value proposition without focusing only on music production and distribution. Moreover, 
digital services like iTunes represented also the opportunity to change the revenue structure, that took a certain relevance year after year, outdoing the physical CDs in $2010^{2}$.

Considering customer orientation, two respondents in two different majors declared that "After the iTunes disruption the company started following the market surveys to better understand the choices of the customers, something that this company had never done before" (MM2) and that "The type of downloads on iTunes gave to the Labels the opportunity to understand the tastes of the users. The observation of these trends and of the new varieties of music that seemed to be successful brought [our company] to an intensive analysis of the market research, which also allowed to appreciate the consumers 'view of every artist" (MM3).

\section{Music Majors facing Spotify}

Looking at the second innovation (Spotify) we no longer consider those strategies that were not relevant in the previous analysis. Thus Spotify, as well as iTunes, created a new channel which is not correlated with the existing assets of the MMs. The analyzed strategies are summarized in Table 6.

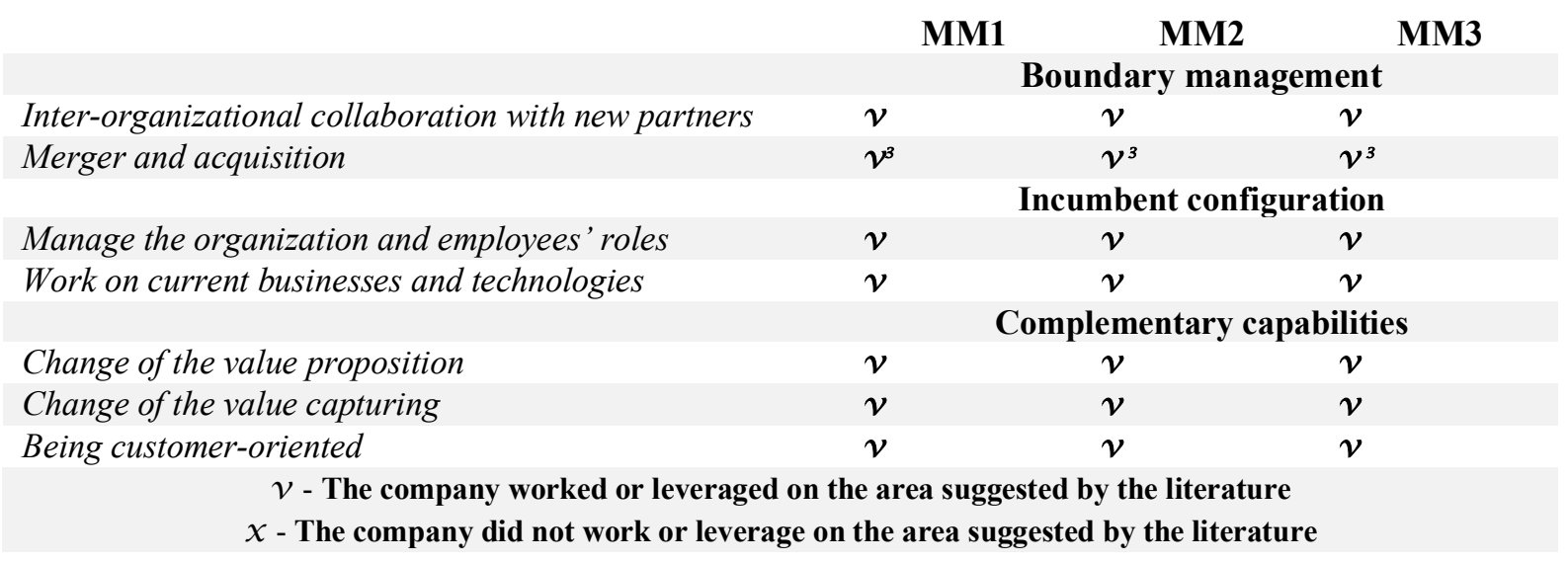

Table 6 - How companies leveraged on selected strategies to survive after Spotify

As in the previous case, the three companies collaborate with service provider such as YouTube and creates joint ventures among them, collaborating also with Spotify and other similar service providers, leveraging once again on the boundary management strategies. Regarding the incumbent configuration and the complementary capabilities, several strategies rely again on the decisions and actions implemented facing iTunes, with even more emphasis: "After this last innovation the lack of interest in the ownership of music has grown again: this gives even more importance to the business that is collateral to the sale of songs and CDs". Also in this case the

\footnotetext{
${ }^{2}$ https://www.theguardian.com/media/2012/jan/06/downloads-physical-sales-us

3 The acquisitions made facing iTunes still impact.
} 
revenue structure for the three majors changed, since streaming services like Spotify offers a play-per-stream revenue model (overtaking digital downloads in 2016 in the USA) ${ }^{4}$.

\section{Discussion}

The analysis of the three case studies through the perspective of their reactions to the innovations proposed by iTunes and Spotify is summarized in Table 7.

\begin{tabular}{|c|c|c|}
\hline & Facing iTunes & Facing Spotify \\
\hline & \multicolumn{2}{|c|}{ Boundary management } \\
\hline Inter-organizational collaboration & $\boldsymbol{v}$ & $\boldsymbol{v}$ \\
\hline \multirow[t]{2}{*}{ Merger and acquisition } & $\boldsymbol{v}$ & $\boldsymbol{v}$ \\
\hline & \multicolumn{2}{|c|}{ Incumbent configuration } \\
\hline Manage the organization and employees' roles & $\boldsymbol{v}$ & $\boldsymbol{v}$ \\
\hline \multirow[t]{2}{*}{ Work on current businesses and technologies } & $v$ & $\nu$ \\
\hline & \multicolumn{2}{|c|}{ Complementary capabilities } \\
\hline Leverage on specialized technologies & $x$ & $x$ \\
\hline Leverage on a privileged access to distribution channels & $x$ & $x$ \\
\hline Leverage on complementary technologies & $x$ & $x$ \\
\hline Change of the value proposition & $v$ & $\mathcal{V}$ \\
\hline Change of the value capturing & $v$ & $v$ \\
\hline Being customer-oriented & $\boldsymbol{v}$ & $\boldsymbol{v}$ \\
\hline
\end{tabular}

At a first glance, we can easily see how: i) the three majors leverage basically on the same strategies, and ii) they react in the same way facing both iTunes and Spotify. Majors leveraged on the same strategies repeatedly to face innovations based on the interplay between technology and meaning. Incumbents opened themselves to the market, accepting the challenges proposed by new entrants, using them as sources for new opportunities.

Analyzing the case more in depth we will consider separately the three different dimensions presented in the theoretical background: boundary management, Incumbent configuration and Complementary capabilities.

\section{Boundary management}

The three majors managed properly their boundaries, opening themselves to external influence and pursuing an open paradigm (Chesbrough, 2003) in two main ways: first they leveraged on inter-organizational collaboration, searching both for old (e.g. retailers to host the in-stores) and

\footnotetext{
$4 \mathrm{http}: / / \mathrm{www} . b l o o m b e r g . c o m / n e w s /$ articles/2016-03-22/apple-s-itunes-overtaken-by-streaming-music-servicesin-sales

${ }^{5}$ The first and the second columns synthetize the results of Table 5 and Table 6 .
} 
new partners (e.g. Youtube, but also iTunes and Spotify), while pursuing M\&As strategies, as suggested by literature (e.g. Powell et al., 1996; Adner and Kapoor, 2010; Hillman et al. 2009). A first contribution of this research is related to the confirmation that this kind of strategies are still valuable even if we are not considering just the technological dimension anymore. Indeed, they understood that to be aligned with the new meaning they could not work on their own but needed new lifeblood coming from the outside.

\section{Incumbent configuration}

These considerations can be directly linked with the second dimension: Incumbent configuration. This dimension is even more interesting than the previous one, since companies somehow enlarged the two considered strategies if compared to the literature.

On the one hand, they changed their internal configuration. If, according to Maier (1982), "the importance of the reallocation of human resources, i.e. an increase in workers' mobility, both within Companies and from one organization to another" is a key factor to react to a technological change, the three MMs did not stop there. When a new meaning is involved this might not be enough. It is necessary to work on the organizational structure (e.g. becoming Entertainment companies), and there is also the need to hire people intrinsically able to understand the new meaning (e.g. creating digital divisions within the organization).

On the other hand, incumbents went on leveraging their current businesses and technologies, pushing the physical market further. According to O'Reilly and Tushman (2008) "the longterm efficiency of the mature units is necessary to continue to compete in an old and in a new market at the same time: old units shall be seen as a strategic asset by the management". Majors leverage on old units selling CDs even after the success of the MP3 technology but they also find new ways to make the old products attractive. Majors have been able to leverage on their Mature Business - represented in a wider perspective by their catalogues - reinventing it through the new meaning. They carried the already existing catalogs on the new services, in order to regain from them. This was permitted by the fact that both innovations were not just technological. In the first case Majors re-sold old songs thanks to two aspects of the new meaning brought by iTunes: the consumer's wish to create his own music and the easier access to music allowed by a cheaper price. Some customers purchased the old songs once again because they could not let them out of their playlists. Others acquired songs for the first time: they would not have bought an entire album but they could easily afford to purchase only one hit. In the same way, through the second innovation Majors are able to propose to the young users also music from the past. 


\section{Complementary capabilities}

Finally, the Complementary capabilities can be considered. On this last dimension, the results of our empirical analysis show a clear distinction. The capabilities related to the complementary assets (e.g. specialized technologies, privileged access to distribution channel and complementary technologies) had not a role in the reaction process, while others related to a dynamic dimension (i.e. change the value proposition, the value capturing and the customer orientation) played a significant role.

Building on this last observation we can provide a two-fold contribution. One the one hand, we can see how a radical innovation that leverage on the interplay between technology and meaning change significantly the assets and the resources that companies need to compete on the market. In this perspective, complementary assets may lose their role in the value capturing process (Teece, 1986). This is coherent with the peculiarities of an innovation that propose also a shift on the meaning domain (Verganti, 2009) changing the dimension of the competition.

On the other hand, the MMs had to push they dynamic capabilities (Teece et al., 1997) and their tendency to change further to react consistently and to absorb the potentialities provided by the external innovations proposed by iTunes and Spotify. As suggested in literature, companies can react by exploring and developing new ways to propose value and capture it (Chesbrough and Rosenbloom, 2002; Chesbrough, 2010; Teece, 2010; Zott et al., 2011). In terms of value proposition, they moved to a wider perspective (i.e. Entertaiment companies), and embraced new value capturing methods through iTunes, Spotify and other fast followers.

Even more interestingly, they significantly leveraged on market-orientation (Chandy and Tellis, 1998; Danneels, 2004).

They always worked in a "push" way, as one of the interviewed managers told us: "We used to sell physical supports, evolved from vinyl to $C D$, with some intermediate format with a limited success, there were just one or few physical supports and they were easy to sell". Only after iTunes and Spotify they realized the relevance of understanding the market: "We moved from a basic marketing approach [...], without doing market researches because the business model was working. [...] We moved to a completely different business model [...], we may have some projects where selling CDs is not easy, but that brand can be sold for appearances, partnership, conventions, activities where there is an economic value, and our work needs to go in that direction too". Trying to understand why users love the new meanings, they went back looking at their customers, realizing how they changed and how much they did not realize it. Incumbents need to become flexible and open, able to accept the market challenges and ready 
to react by exploring new opportunities leveraging on the resources that brought them in a leading position.

Moreover, incumbents need to fully understand the opportunities that innovators provide. Majors needed to look at customers that already interpreted and owned the new meaning, in order to understand which was the promise that new entrants were proposing them. This is completely different from the approach normally applied to develop an innovation of meaning: when a company searches for an innovation in this domain normally looks for many interpreters, people that can bring new perspectives in the field and let the company unveil a new reason why (Verganti, 2008; Jepsen et al., 2014; Morillo et al., 2015; Verganti, 2016). On the contrary, to react to an external innovation of technology and meaning MMs showed the need to re-think about their own role in the industry.

External innovators (first iTunes and then Spotify) challenged the status quo that incumbent firms where in. Since the meaning is a promise to the user, the reason why users love a product or a service (Verganti, 2008), incumbents can leverage on a multi-meaning strategy (Figure 2).

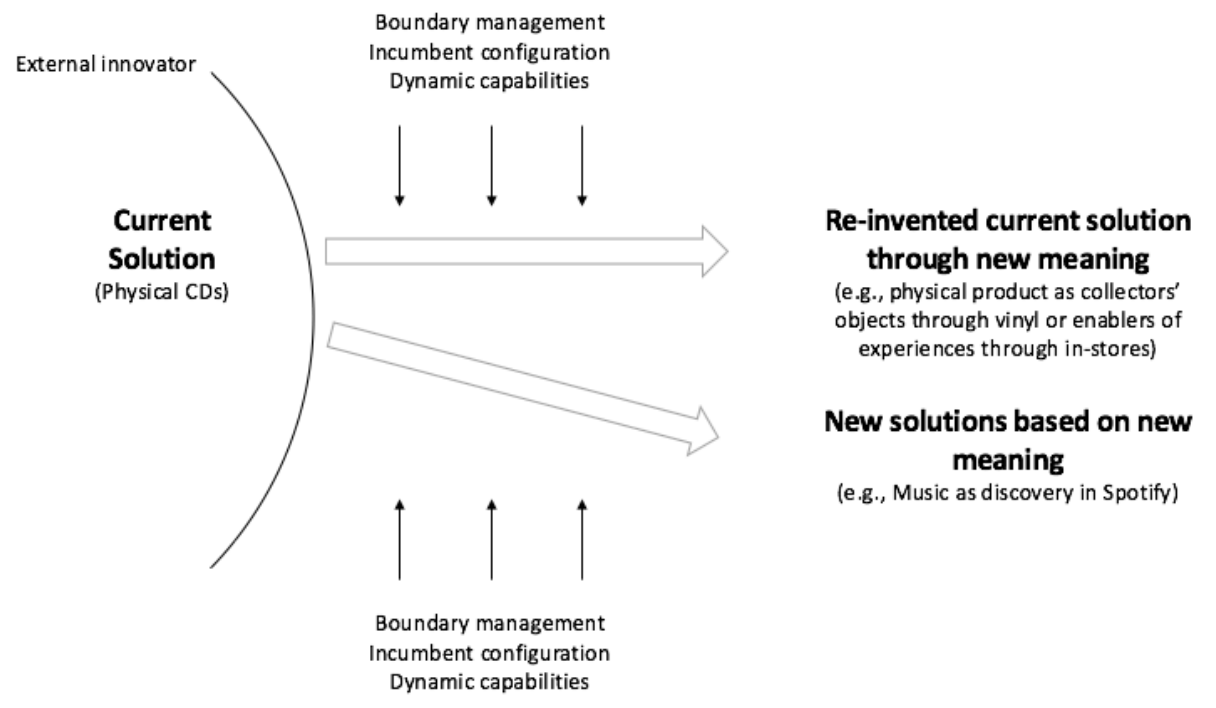

Figure 2 - Incumbents' reacting to external innovation based on the interplay between technology and meaning

On one hand companies have the necessary assets to go on working on the current solution, but they also work to re-interpret the current solution. In the considered empirical field this is extremely clear. Being challenged on the physical market the MMs started to re-think the physical products. For example, they moved CDs to the experience level, through in-stores to increase the physical sales. On the other hand, they explored the opportunities provided by the 
new entrants, re-inventing their businesses to embrace the new paradigm (e.g. creating their own branded playlists on Spotify).

The two incumbent reactions leverage on the three strategies (i.e. Boundary management, Incumbent configuration and Dynamic Capabilities) both to re-interpret the current solution through new meaning and to leverage new solutions based on the new meaning.

Observing the industry from a wider perspective, it is possible to see how MMs have been able to fully leverage the multi-meaning perspective, capturing value from both of them. After the initial iTunes growth (and then after the Spotify one as well), they leveraged the old meaning giving it even a wider role for a market niche. Users started to buy physical objects again, with an incredible growth of vinyl (with a 54\% sales increase in 2014 in the $\mathrm{USA}^{6}$ ). The old meaning resulted reinforced since it was distant from what the large majority of users was searching for.

\section{Conclusions and Implications}

The purpose of this research is to understand if the strategies useful to react to technology-push innovations are still useful when external innovators leverage also the meaning dimension. The paper is built onto the literature streams that consider the strategies that incumbents can rely on to react to external innovations in the technological domain.

The Music Industry has been used as empirical field, considering three MMs as case studies, since it faced the innovative force of new entrants several times in less than two decades. iTunes and Spotify have been highlighted as the two more significant innovations that leveraged both on technology and meaning. iTunes let users consider the songs on their iPods as "their music" and made people willing to pay for what they were listening to even if in those years the popularity of illegal download was particularly high. Through Spotify the attention moved to the chance to get the perfect music for that moment through algorithms and suggested playlists. Through a literature search and review we highlighted ten strategies that incumbents can implement to survive after a radical innovation in the technological domain, leveraging the work of Ansari and Krop (2012). Through primary and secondary sources, we analyzed the behaviors of MMs coping with the two identified innovations, in order to understand what kind of strategies and concrete managerial actions they implemented to react to external innovators.

\footnotetext{
${ }^{6}$ http://www.ifpi.org/facts-and-stats.php
} 


\section{Academic contribution}

From an academic perspective, this research enlarges the current knowledge on the incumbent's curse and strategies that companies can pursue to survive to external innovators. This research is aligned with those that rely on the incumbent's survival (e.g Chandy and Tellis, 2000), falsifying the incumbent's curse. In particular, considering the similarities and differences in terms of strategies to react when the innovation dimensions involved also the meaning, and not just the technological side. Those strategies that push in terms of boundary management (e.g. Powell, et al., 1996; Chesbrough, 2005; Iansiti et al., 2003; Kapoor and Adner, 2011) and in terms of incumbent configuration (e.g., Hill and Rothaermel, 2003; Voss et al., 2006; O'Reilly and Tushman, 2008) are still valuable and seems to play a key role. Otherwise, the strategies regarding Complementary capabilities are valuable in the meaning dimension only under specific circumstances. Indeed, the complementary assets (Teece, 1986), valuable to react to shifts in the technological domain, are not so relevant anymore when external innovators leverage also on the meaning dimension. Indeed, the strategies more related to the capabilities to adapt and to change the business model (e.g. Zott et al., 2011) and to foster a customer orientation (e.g. Dannel, 2004; Taylor and Helfat, 2009) are extremely important to adapt the business to the new status quo. These three dimensions lead companies to create and capture value leveraging both on the current solution (through the new meaning) and on new solutions (unveiled through external innovators).

Finally, a last contribution can be found also in the growing literature on the interplay between technology and meaning (Verganti, 2009; Buganza, et al., 2015; Dell'Era, 2017). Companies can still focus on their current businesses (O'Reilly and Tushman, 2008) but with a new perspective, getting the chance to leverage on a multi-meaning strategy, embracing the new one and re-inventing the previous standard.

\section{Managerial implications}

From a managerial perspective, we can highlight some key points that companies facing an innovation that leverage on the interplay between technology and meaning proposed by new entrants should consider to successfully survive on the market.

Companies need to deeply understand the leverages used by new entrants. They need to understand the reasons why users are in love with the new meanings, how their needs are changing and they need to question their traditional approach to the market. During this process incumbents also need to consider how their competitive advantage may be useful to re-enforce their position in the market. Indeed, companies may use their position in order to enlarge the 
spectrum of their activities or leverage on their network of relationships to develop new business activities coherent with the new meaning and re-inventing the previous one.

Incumbents need to understand that a reactive strategy is the best way to face this kind of innovations. New entrants may change the status quo, but they can also provide great opportunities for incumbents. Indeed, being challenged by external innovators can be the trigger point to start re-thinking how the business work, challenging old paradigms (e.g. MMs did not rely heavily on market research, while they do now consider more deeply how the customers change) and providing new and fresh insights to re-think about the current situation.

\section{Limitations and Future Research}

This exploratory research let us understand something more about how incumbents can react to an external innovator of meaning proposed by a new entrant. Limitations are strictly related to how we designed our research. Even if through these case studies we analyzed the behaviors of more than the $88 \%$ of the incumbents, we focused on a single industry, reducing the generalizability of results. Our findings can fit other industries with similar peculiarities, such as other content based industries (e.g. cinema, publishing), where similar new meanings are being proposed or may be proposed. Future researches may focus on different industries to deep in understanding how incumbents can cope with new meanings proposed by new entrants. 


\section{References}

Abernathy, W. J., \& Clark, K. B. (1985). Innovation: Mapping the winds of creative destruction. Research policy, 14(1), 3-22.

Adner, R. (2002). When are technologies disruptive? A demand-based view of the emergence of competition. Strategic Management Journal, 23(8), 667-688.

Ahuja, G., \& Morris Lampert, C. (2001). Entrepreneurship in the large corporation: A longitudinal study of how established firms create breakthrough inventions. Strategic management journal, 22(6-7), 521-543.

Aiken, M., \& Hage, J. (1971). The organic organization and innovation. Sociology, 5(1), 63-82.

Ansari, S. S. and Krop, P. (2012) Incumbent performance in the face of a radical innovation: Towards a framework for incumbent challenger dynamics. Research policy, 41(8), 1357-1374.

Barney, J. (1991) Firm resources and sustained competitive advantage. Journal of management, 17(1), 99-120.

Beltagui, A., M. Candi, and J. Riedel. (2012). Designing in the experience economy. In Interdisciplinary approaches to international marketing: Creative research on branding, product design/innovation, and strategic thought/social entrepreneurship. advances in international market- ing series (Vol. 23), ed. S. Zou and S. Swan, 111-35. Bingley, UK: Emerald Group Publishing Limited.

Brusoni, S., Prencipe, A., \& Pavitt, K. (2001). Knowledge specialization, organizational coupling, and the boundaries of the firm: why do firms know more than they make? Administrative science quarterly, 46(4), 597-621.

Bryman, A. and Bell, E. (2015) Business research methods, Oxford university press.

Brynjolfsson, E., and A. McAfee. 2014. The second machine age: Work, progress, and prosperity in a time of brilliant technologies: WW Norton \& Company.

Brynjolfsson, E., Hu, Y., \& Smith, M. D. (2003). Consumer surplus in the digital economy: Estimating the value of increased product variety at online booksellers. Management Science, 49(11), 1580-1596.

Buganza, T., Dell'Era, C., Pellizzoni, E., Trabucchi, D. and Verganti., R. (2015) Unveiling the Potentialities Provided by New Technologies: A Process to Pursue Technology Epiphanies in the Smartphone App Industry. Creativity and Innovation Management, 24(3), 391-414

Candi, M., Ende, J., \& Gemser, G. (2015). Benefits of Customer Codevelopment of New Products: The Moderating Effects of Utilitarian and Hedonic Radicalness. Journal of Product Innovation Management.

Cardinal, L. B. (2001). Technological innovation in the pharmaceutical industry: The use of organizational control in managing research and development. Organization science, 12(1), 19-36.

Cattani, G. (2005). Preadaptation, firm heterogeneity, and technological performance: a study on the evolution of fiber optics, 1970-1995. Organization Science, 16(6), 563-580.

Chandy, R. K. and Tellis, G. J. (2000) The Incumbent's curse? Incumbency, Size and Radical Product Innovation. Journal of Marketing , 64 (3), 1-17.

Chesbrough, H. (2003). The logic of open innovation: managing intellectual property. California Management Review, 45(3), 33-58.

Chesbrough, H. (2006). Open innovation: a new paradigm for understanding industrial innovation. Open innovation: Researching a new paradigm, 400, 0-19.

Chesbrough, H. (2010) Business model innovation: opportunities and barriers. Long range planning, 43(2), 354363. 
Chesbrough, H. and Rosenbloom, R. S. (2002) The role of the business model in capturing value from innovation: evidence from Xerox Corporation's technology spin-off companies. Industrial and corporate change, 11(3), 529-555.

Christensen, C. M. (2006). The ongoing process of building a theory of disruption. Journal of Product innovation management, 23(1), 39-55.

Christensen, C. M. and Bower, J. L. (1996) Customer power, strategic investment, and the failure of leading firms. Strategic management journal, 17(3), 197-218.

Christensen, C. M., \& Rosenbloom, R. S. (1995). Explaining the attacker's advantage: Technological paradigms, organizational dynamics, and the value network. Research policy, 24(2), 233-257.

Christenson, C. (1997). The innovator's dilemma. Harvard Business School Press, Cambridge, Mass.

Cohan, P. S. (2000). The Dilemma of the "Innovator's Dilemma': Clayton Christensen's Management Theories Are Suddenly All the Rage, but Are They Ripe for Disruption. Industry Standard, 10, 2000.

Cohen, W. M., \& Levinthal, D. A. (1990). Absorptive capacity: A new perspective on learning and innovation. Administrative science quarterly, 128-152.

Damanpour, F. (1991). Organizational innovation: A meta-analysis of effects of determinants and moderators. Academy of management journal, 34(3), 555-590.

Danneels, E. (2004). Disruptive technology reconsidered: A critique and research agenda. Journal of product innovation management, 21(4), 246-258.

Dell'Era, C., Marchesi, A. and Verganti, R. (2010) Mastering Technologies in design-driven innovation. ResearchTechnology Management, 53(2), 12-23.

Dell'Era, C., N. Altuna, S. Magistretti, and R. Verganti. (2017). Discovering quiescent meanings in technologies: exploring the design management practices that support the development of Technology Epiphanies. Technology Analysis and Strategic Management 29(2): 149-166.

Downes, L., \& Nunes, P. (2013). Big bang disruption.

Dushnitsky, G. and Lenox, M. J. (2005) When do incumbents learn from entrepreneurial ventures?: Corporate venture capital and investing firm innovation rates. Research Policy, 34(5), 615-639.

Eisenhardt, K. M. and Graebner., M. E., (2007) Theory building from cases: opportunities and challenges. Academy of Management Journal 50(1): 25-32.

Gawer, A. and Cusumano, M. A. (2008) How companies become platform leaders. MIT Sloan management review, 49(2), 28.

Gibbert, M., Ruigrok, W. and Wicki, B. (2008) What Passes as a Rigorous Case Study? Strategic Management Journal, 29, 1465-74.

Hage, J. T. (1999). Organizational innovation and organizational change. Annual review of sociology, 25(1), 597622.

Helfat, C. E., \& Lieberman, M. B. (2002). The birth of capabilities: market entry and the importance of prehistory. Industrial and corporate change, 11(4), 725-760.

Henderson, R. (1993) Underinvestment and incompetence as responses to radical innovation: Evidence from the photolithographic alignment equipment industry. The Rand Journal of Economics, 24(2), 248-270.

Hill, C. W., \& Rothaermel, F. T. (2003). The performance of incumbent firms in the face of radical technological innovation. Academy of Management Review, 28(2), 257-274. 
Hillman, A. J., Withers, M. C., \& Collins, B. J. (2009). Resource dependence theory: A review. Journal of management.

Iansiti, M., McFarlan, F. W., \& Westerman, G. (2003). Leveraging the incumbent's advantage. MIT Sloan Management Review, 44(4), 58-65.

Jepsen, L. B., Dell'Era, C. and Verganti, R. (2014). The contributions of interpreters to the development of radical innovations of meanings: the role of 'Pioneering Projects' in the sustainable buildings industry. R\&D Management, 44(1), 1-17.

Kapoor, R., \& Adner, R. (2012). What firms make vs. what they know: how firms' production and knowledge boundaries affect competitive advantage in the face of technological change. Organization Science, 23(5), 1227-1248.

King, A. A., \& Tucci, C. L. (2002). Incumbent entry into new market niches: The role of experience and managerial choice in the creation of dynamic capabilities. Management science, 48(2), 171-186.

King, A., \& Tucci, C. L. (2000). Responding to Technology-Created Market Niches: Do Industry-Specialized Capabilities Facilitate or Hamper Entry?. In Academy of Management Proceedings (Vol. 2000, No. 1, pp. D1-D6). Academy of Management.

Klepper, S., \& Simons, K. L. (2000). Dominance by birthright: entry of prior radio producers and competitive ramifications in the US television receiver industry. Strategic Management Journal, 997-1016.

Lambe, C. J. and Spekman, R. E. (1997) Alliances, external technology acquisition, and discontinuous technological change. Journal of product innovation management, 14(2), 102-116.

Leifer, R. (2000). Radical innovation: How mature companies can outsmart upstarts. Harvard Business Press.

Macher, J. T., \& Richman, B. D. (2004). Organisational responses to discontinuous innovation: a case study approach. International Journal of Innovation Management, 8(01), 87-114.

MacMillan, I. C., \& Selden, L. (2008). The incumbent's advantage. Harvard business review, 86(10).

Maier, H. (1982) Innovation, efficiency, and the quantitative and qualitative demand for human resources. Technological Forecasting and Social Change, 21(1), 15-31.

Makri, M., Hitt, M. A. and Lane, P. J. (2010) Complementary technologies, knowledge relatedness, and invention outcomes in high technology mergers and acquisitions. Strategic Management Journal, 31(6), 602-628.

Merton, R., Fiske, M. and Kendall, P. (1990) The focused interviews: a manual of problems and procedures 2nd edition.

Methe, D., Swaminathan, A., Mitchell, W., \& Toyama, R. (1997). The underemphasized role of diversifying entrants and industry incumbents as the sources of major innovations. Strategic Discovery: Competing in New Arenas, 99-116.

Miles, M. B. and Huberman, A. M. (1984) Qualitative data analysis: An expanded sourcebook. Sage.

Mittal, S. and Swami, S. (2004) What factors influence pioneering advantage of companies?. Vikalpa, 29(3), 15.

Morillo, M., Dell'Era, C. and Verganti, R. (2015) Exploring the role of 'outsider' interpreters in the development of design-driven innovations. International Journal of Technology Intelligence and Planning, 10(3-4), 222253.

Norman, D. and Verganti, R. (2014) Incremental and Radical Innovation: Design Research vs. Technology and Meaning Change. Design Issues, 30(1), 78-96. 
O’Reilly, C. A. and Tushman, M. L. (2008) Ambidexterity as a dynamic capability: Resolving the innovator's dilemma. Research in organizational behavior, 28, 185-206

Pierce, J. L., \& Delbecq, A. L. (1977). Organization structure, individual attitudes and innovation. Academy of management review, 2(1), 27-37. Damanpour, F. (1991). Organizational innovation: A meta-analysis of effects of determinants and moderators. Academy of management journal, 34(3), 555-590.

Podolny, J. M., Khurana, R. and Hill-Popper, M. (2004) Revisiting the meaning of leadership. Research in organizational behavior, 26, 1-36.

Powell, W. W., Koput, K. W. and Smith-Doerr, L. (1996) Interorganizational collaboration and the locus of innovation: Networks of learning in biotechnology. Administrative science quarterly, 116-145.

Rosenbloom, R. S. and Christensen, C. M. (1994) Technological discontinuities, organizational capabilities, and strategic commitments. Industrial and corporate change, 3(3), 655-685.

Rosenkopf, L., \& Nerkar, A. (2001). Beyond local search: boundary-spanning, exploration, and impact in the optical disk industry. Strategic Management Journal, 22(4), 287-306.

Rothaermel, F. T. (2001). Incumbent's advantage through exploiting complementary assets via interfirm cooperation. Strategic Management Journal, 22(6-7), 687-699.

Rothaermel, F. T., \& Boeker, W. (2008). Old technology meets new technology: Complementarities, similarities, and alliance formation. Strategic Management Journal, 29(1), 47-77.

Rothaermel, F. T., \& Hill, C. W. (2005). Technological discontinuities and complementary assets: A longitudinal study of industry and firm performance. Organization Science, 16(1), 52-70.

Saldaña, J. (2012) The coding manual for qualitative researchers (No. 14). Sage.

Sampson, R. C. (2005). Experience effects and collaborative returns in R\&D alliances. Strategic Management Journal, 26(11), 1009-1031.

Schumpeter, J. A. (1942). Capitalism, Socialism, and Democracy: Harper and Brothers, New York.

Schwartz, B. 2004. The paradox of choice: Why more is less. New York: Ecco.

Simoni, M., Cautela, C. and Zurlo, F. (2014) Product Design Strategies in Technological Shifts: An Explorative Study of Italian Design-Driven Companies. Technovation, 34, 702-15.

Slater, S. F., \& Narver, J. C. (1998). Customer-led and market-oriented: Let's not confuse the two. Strategic management journal, 1001-1006.

Teece, D. J. (1986) Profiting from technological innovation: Implications for integration, collaboration, licensing and public policy. Research policy, 15(6), 285-305.

Teece, D. J. (2010) Business models, business strategy and innovation. Long range planning, 43(2), 172-194.

Teece, D. J., Pisano, G. and Shuen, A. (1997) Dynamic capabilities and strategic management. Strategic Management Journal, 18(7), 509-533.

Thomond, P., Herzberg, T., \& Lettice, F. (2003). Disruptive innovation: Removing the innovators dilemma. In British Academy of Management Annual Conference: Knowledge into Practice

Tripsas, M. (1997) Unraveling the Process of Creative Destruction: Complementary Assets and Incumbent Survival in the Typesetter Industry. Strategic Management Journal, 18(S1), 119-142.

Tushman, M. L. and Anderson, P. (1986) Technological discontinuities and organizational environments. Administrative science quarterly, 439-465. 
Verganti, R. (2008) Design, Meanings and Radical Innovation: A Metamodel and a Research Agenda. Product Innovation Management Journal, 25(5), 436-456.

Verganti, R. (2009). Design driven innovation. Harvard Business School Press, Boston.

Verganti, R. (2011) Radical design and technology epiphanies: A new focus for research on design management. Journal of Product Innovation Management, 28, 384-388.

Verganti, R. (2016) The innovative power of criticism. Harvard business review, 94(1), 18.

Verganti, R. (2017). Overcrowded: Designing Meaningful Products in a World Awash With Ideas. Boston: MIT Press.

Verganti, R. and Öberg, Å. (2013) Interpreting and envisioning - A hermeneutic framework to look at radical innovation of meanings. Industrial Marketing Management, 42(1), 86-95.

Voss, Z. G., Cable, D. M. and Voss, G. B. (2006) Organizational identity and firm performance: What happens when leaders disagree about “who we are?". Organization Science, 17(6), 741-755.

Westerman, G., McFarlan, F. W., \& Iansiti, M. (2006). Organization design and effectiveness over the innovation life cycle. Organization Science, 17(2), 230-238.

Yin, R. K. (1998) The abridged version of case study research. Bickman and Rog.

Yin, R. K. (2009) How to do better case studies. The SAGE handbook of applied social research methods, 2, 254282.

Zott, C., Amit, R. and Massa, L. (2011) The Business Model: Recent Developments and Future Research. Journal of Management, 37(4), 1019-104. 